\title{
Data Sharing and Archiving Qualitative and QL Data in Poland
}

\author{
by Piotr Binder and Piotr Filipkowski
}

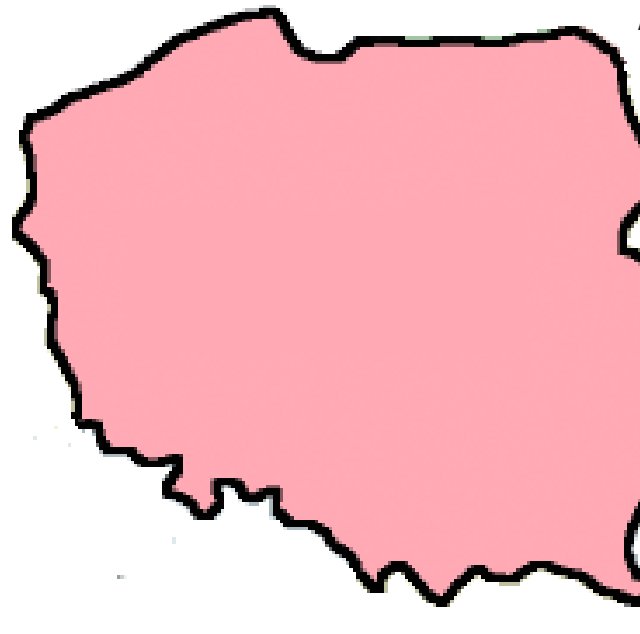

and are

focused on oral history documentation and research project (which we count

among qualitative research); some examples of longitudinal studies are also mentioned. Finally we are trying to formulate key problems impeding development of the field - without loosing conviction, they will be overcome.

Keywords: data sharing, archiving, qualitative data, Qualitative longitudinal research, oral history, Poland.

To what extent is data sharing or archiving for re-use part of the research culture in Poland? Based on the example of probably all social sciences it might be said that data sharing is not a part of research culture at all. There has been no academic tradition of such kind in social sciences in Poland. Although the problem is being brought up at least occasionally no significant change has been noticed within the rather conservative sociological main stream.
Furthermore, whereas some social scientists are skeptical about sharing their own data, others, e.g. anthropologist, are reluctant even to use qualitative data not gathered by themselves (their motto: the researcher has to soak in the atmosphere of the field","only he/she knows what is the real meaning of the collected materials, because he/she was there, usually for a long period, he/she experienced the situation and as a consequence only he/she can properly interpret the data"). Therefore, it is more likely that using someone else's qualitative data in a project (obviously with a permission of the author) might cause deep methodological concerns of more experienced colleagues rather than arouse academic interest or approval.

\section{some social scientists are skeptical about sharing their own data}

As a result, on the level of everyday practice most of the data collected in the field has a "disposable" character. Once the publication is ready they find their place in the researcher's desk drawer. Exceptions are being made for close co-workers, assistants, selected PhD and MA students, mostly in the situations when they join particular research teams and/or continue the work of their predecessors (very often their supervisors).

Apart from what Paul Thompson called "sitting on data" there is also an important question of reliability of sources. For instance most of the contemporary Polish historians treat sources like recorded interviews as untrustworthy. The dominant approach in historiography has been deeply positivistic and, as such, too strict to develop research based on oral history interviewing. This group of researchers had to deal also with a problem of political character. Oral history has been often understood as some sort of 
"history from below" or as "giving voice to the voiceless", which before 1989 was ideologically uncomfortable and treated as suspicious in the official historiography in Poland.

What is interesting is that institutions and projects that are oriented towards archiving qualitative data do exist. This report provides many examples of such initiatives. Although some of them are relatively advanced, they do not compose a network, but constitute rather a group of dispersed and diversified projects facing similar problems and very often competing with each other especially in the area of funding. However what must be stressed - and this is crucial for this document - is that archiving institutions function practically outside academia. Contacts between both sides are loose and based on individual rather than inter-institutional cooperation.

The existence of one only - and until now not a very successful one - official archive of qualitative data affiliated at the academic institution in Poland proves that changing the existing patterns and introducing new ones is not an easy task to do. Nevertheless, the authors would like to believe that with efficient cooperation and exchange of information as well as with effective promotion of good practices some "qualitative change" will be possible even within very conservative Polish academic circles.

\section{Existing qualitative archiving infrastructure:}

After what has been stated in the introduction one can expect not to read much about existing infrastructure for archiving qualitative data of an academic character in Poland. To a vast extent those intuitions are true, because at the present time there is only one enterprise of such kind.

\section{Qualitative Data Archive [Archiwum Danych Jakościowych ADJ]²} $A D J$ is an initiative of a group of researchers from the Institute of Philosophy and Sociology of the Polish Academy of Sciences (IFiS PAN) to establish an archive of qualitative data. Unfortunately, after almost five years of experiences it is still at its very initial stage. Problems with financing as well as with the common practice of not sharing gathered data have limited development and expansion. The milieu of researchers involved in this initiative grows slowly, however, working pro-bono they keep collecting qualitative data. Apart from those coming from their personal research project (e.g. over 200 interviews with young people gathered within a project Generation 1989) they managed to save the entire collection of fieldwork materials from 1970s and 1980s (from tape-recorded interviews and fieldwork notes to photographs and family budgets) of the team of Professor Andrzej Siciński (which is discussed below).

In the last months there has been more intensive discussion at the Polish Academy of Science on the need to develop and expand qualitative archiving. We would like to start with data collections produced in different project realised within the Academy, but also start collecting 'external' data. The key obstacle is lack of additional funds for this initiative.

\section{Existing qualitative archiving infrastructure of non- academic character}

\section{Oral History Archive of the KARTA Centre and History Meeting House ${ }^{3}$ in Warsaw}

This was the first Polish initiative that started to record, collect and archive qualitative data in a systematic way on a wider scale. Until now it is also the biggest and the most diversified collection of qualitative data in Poland.

Karta started in the early 1980's as a milieu of young dissidents who decided to oppose the official system through gathering, preserving and publicizing documentation (including: memoires, diaries, interviews, pictures, documents etc.) regarding individuals and groups "forgotten" or rather neglected in the political mainstream. In the 1980's KARTA managed to establish the so called Eastern Archive, where approximately 1200 interviews with Poles repressed by the Soviet State were stored. Additionally, KARTA's activists were conducting interviews with Polish dissidents, people who, in various ways, actively opposed the communist system before 1989 .

These two experiences were of a decisive character. In 2002 a decision was made to invite KARTA to participate in the Mauthausen Survivors Documentation Project. It was the biggest European oral history project devoted to a single Nazi concentration camp. Over 860 interviews were conducted all over the Europe in the United States and Israel. KARTA recorded and elaborated over 160 biographical narrative interviews with Polish Mauthausen survivors. The strong position of KARTA was highlighted by the fact that, unlike in other participating countries, the Polish part of the project was coordinated by a nonacademic institution.

The experience of the Mauthausen Project forced KARTA to establish a permanent Oral History Programme and create a modern oral history archive. The process that started at that time has had a long and difficult history. However thanks to generous support of institutions like the European Commission, the Polish Senate (the upper chamber of the parliament), German Foundation "Remembrance, Responsibility and Future" and the Polish Committee of Scientific Research, within the past few years KARTA has completed several significant oral history projects. Nevertheless it needs to be stressed that the financial side of creating an entirely new archiving infrastructure without stable institutional or state support is particularly challenging.

The archive could not function and develop so intensively without the support of the History Meeting House $(\mathrm{HMH})$, a municipal institution of culture established in 2006 on Karta's initiative. The archive itself belongs to both institutions (physically it is located at the History Meeting House). Thanks to this co-operation the oral history collection could be digitalised (including the interviews collected in 1980's), catalogued and partly published on the website: www.audiohistoria.pl (full access available on the premises of $\mathrm{HMH}$ ). Each interview is accompanied with a questionnaire, biographical data of the interviewee and short description of the narrative together with interviewer's remarks regarding the interview situation. Unfortunately, due to the lack of sufficient sources only selected stories could be transcribed.

\section{Museum of Warsaw Uprising ${ }^{4}$}

Shortly after its opening in 2004 a separate oral history unit was established to conduct, collect and make accessible interviews with Polish soldiers of the Warsaw Uprising. Up to now approximately 2000 video interviews have been recorded. Edited transcripts are available online, with full recordings at the premises of the museum. In 2008 the museum published a catalogue of its oral history collection. The Museum of Warsaw Uprising is a state funded institution with a stable budget. Its oral history archive is additionally supported on a regular basis by one of the biggest Polish banks.

Brama Grodzka - Teatr NN In Lublin ${ }^{5}$ 
The institution itself has existed since 1990, and its oral history programme since 1998. Brama Grodzka is active in the Lublin area (in the South-East of Poland) the region that until WWII was particularly multi-ethnic and multicultural. Although its pre-war past constitutes the main focus of interest, the institution is also running other related projects e.g. to WWII or democratic opposition in Poland.

Brama Grodzka has collected and archived approximately 800 audio (and some video) interviews. Partial access to this collection is possible over the internet, full at the premises of the institution. Brama Grodzka cooperates with Public Radio Lublin, which created the Oral History Studio. As a municipal cultural institution it is maintained by the city of Lublin.

These are the biggest and most advanced (also in archiving and reusing) Oral History initiatives in Poland. Since several years, there are many smaller projects operating at the moment. Some of them are listed at the end (see Appendix II). These various activities in the field of oral history are not only dispersed but there is also very little discussion and cooperation between them. However the need to integrate the milieu has already been perceived. In autumn 2007 the first international conference on oral history in Poland was organized in Kraków (Oral History: The Art of Dialogue). This event was followed by the setting up of the Polish Oral History Association in January 2009. The platform for discussions, exchange has appeared. One of the goals is to create a database covering all Polish oral history initiatives and introduce common standards of description and archiving of collected material.

\section{Qualitative longitudinal (QLL) data}

(i.e., data of diverse formats (interviews, videos etc.) addressing time and temporality gathered in follow-up and repeat cross sectional studies, and retrospective studies such as life and oral histories)

Due to the fact that there is no access to data collections of most of academic research projects we have decided to provide some examples - although not many -of: longitudinal studies or projects involving follow-up studies, repeated studies or retrospective studies. Additionally, where possible, contact details of the heads of the projects or people who possess collected data sets are provided.

1) Repeated monographs of local communities: Monographs of local communities along with the analyses of personal documents and competitions of memoirs once gained the title of being the "calling card" of Polish empirical sociology (to mention only "The Polish Peasant in Europe and America" edited by F. Znaniecki and W.I. Thomas, 1918-1920).

Chronologically the first monographs in Poland were written by ethnographers. The greatest achievement of the 19th century was The People, an 86-volume work by Oskar Kolberg. The beginning of the 20th century was a time of 'economic' monographs e.g. by Franciszek Bujak $(1901,1903)$. Those monographs that are regarded in Polish sociology as "sociological" appeared only after that and were usually focused on a particular problem - so called problem monographs e.g. The Polish-German Antagonism in the Factory Settlement "Kopalnia" in Upper Silesia by Józef Chałasiński (1935).

Although neglected in the 1970s, they have been recently gaining interest, together with the growing popularity of the ideas of localism and local problems in social sciences in Poland after 1989.
Examples:

- Bujak, Franciszek. 1901. Maszkienice - Village of Brzeg County. Economic and Social Relations.

- Bujak, Franciszek. 1911. Maszkienice - Village of Brzeg County. From 1901 to 1911.

- Zawistowicz-Adamska, Kazimiera. 1948. Rural Community: Experiences and Delibeations. (based on fieldwork conducted in Zaborów village in 1938)

- Wieruszewska, Maria. 1978. Transformation of local Community. Zaborów after 35 Years.

- Bujak, Zbigniew. 1903. Żmiąca -Village of the Limanowa County. Economic and Social Relations.

- Wierzbicki, Zbigniew. 1963. Żmiąca Half a Century Later.

- Łuczewski, Michał. 2007. National Experience in Everyday Life. Problem monograph of Żmiąca Village: 1370-20076.

2) Research on life styles ${ }^{7}$

In the 1970's and 1980's the team of Professor Andrzej Siciński from the Institute of Philosophy and Sociology of the Polish Academy of Science was running a project on life styles of individuals and families in Polish cities. Throughout this time each team member was cooperating with several families. A wide variety of qualitative methods were applied: from participant observation, in-depth interviews and documents to photographs and home budgets. The main outcome of the project was six volumes edited by Siciński between 1976 and 1988.

3) Research on poverty ${ }^{8}$

Since the mid-1990's three sociologists, namely Elżbieta Tarkowska (Polish Academy of Sciences), Kazimiera Wódz (University of Silesia) and Wielisława Warzywoda-Kruszyńska (University of Lódź) have jointly conducted research on various aspects of poverty in Poland. Part of the interest is devoted to the inhabitants of the former collective state farms. After conducting a wave of interviews with several members of each selected family in 2003, Elżbieta Tarkowska came back to her respondents in 2007. In effect two edited volumes were published in 2004 and 2008.

Additionally, one of the books of the team was composed mostly of the selected interviews preceded with a short commentary (Tarkowska, Warzywoda-Kruszyńska, Wódz, Poor People about Themselves and Their Lives, Katowice-Warszawa 2003).

\section{Examples of quantitative longitudinal research conducted in Poland}

1) Research on primary and secondary school pupils ${ }^{9}$ Longitudinal research was conducted between mid-1970's and mid1990's on whole cohorts of school children in the Torun and Włocławek regions by the team of sociologists from University of Nicolaus Copernicus in Torun headed by Professors Zbigniew Kwieciński and Ryszard Borowicz. Until the mid-1990's the dominant technique was audience questionnaire. After the introduction in Poland of the Personal Data Protection Act in 1997, the research team decided to change the character of the project and base it on representative samples.

2) Social structure in Poland. Dynamic analysis in the international context ${ }^{10}$

A research team of sociologists from the Institute of Philosophy and Sociology of the Polish Academy of Sciences (Kazimierz Słomczyński 
- head, Henryk Domański, Bogdan Mach, Krystyna Janicka et al.) between 1988 and 2008, conducted 5 waves of their panel research project. This group of scientists has managed to continue their work on the project in spite of difficulties related to the new law regulations (Personal Data Protection Act from 1997). They publish regularly the outcomes of their research in the form of books and articles (both in Polish and English).

\section{Development planning:}

Although thank to various initiatives a significant amount of qualitative data have been collected over recent years, there are serious gaps within the existing framework:

a) Data sharing or archiving for re-use is not a part of the research culture within the field of social sciences in Poland;

b) Social scientists are not only reluctant to share the data collected by themselves, but also to use the available data collected by other researchers. As an effect only a very little involvement of the academic researchers in the initiatives devoted to collecting qualitative data can be observed;

c) There is no balance between collecting data and analysing it. What is more, some of the institutions mentioned in this report focus entirely on collecting data. The task they fulfil is very important; however it would be very good if the qualitative material gathered with so much investment of time, effort and financial sources aroused interest of the analysts as well.

d) There is still very little communication between institutions collecting qualitative data on various levels. This lack of exchange of sometimes basic information causes situations when several projects overlap with each other or even repeat the same type of interviews with the same people over a short period of time.

e) Institutions collecting qualitative data constantly suffer shortages of financial sources to the extent that very often they do not have enough money for the creation of professional catalogues and computer databases, and furthermore, not enough for good quality recordings that could be used later as audio/video materials (and not only the basis for transcriptions).

f) The Personal Data Protection Act from 1997 constitutes a separate question. Despite the fears of many researchers, its introduction was not the end of social research in Poland. Institutions and research teams have to follow certain regulations, however conducting research (including research of a longitudinal character) and collecting data is still very much possible. Therefore it is not entirely clear why the group of sociologists from Torun claims that they were "forced" to reshape their longitudinal project whereas the team of Professor Słomczyński from the Polish Academy of Sciences continues its work (discussed above).

In terms of priorities for development over the next three years, the main priority is probably a gradual change in the dominant research patterns and practices within the area of social sciences. This naturally will be a long-term process, nevertheless certain actions could be taken. A strategy of building closer relations with academia based on already existing infrastructure (although its condition is not satisfactory) seems to be a natural direction.

Financial support is always very much appreciated, however existing organizations (IASSIST, CESSDA) could provide something equally important, namely intellectual support. Polish institutions dealing with archiving of the qualitative data are still very little advanced, therefore assistance and advice of more experienced partners might help avoid many mistakes and thereby have a significant influence on future development.

\section{References}

Bujak, F. (1903). Zmiaca wies powiatu limanowskeigo. Montanta: Kessinger

Chałasiński, J. (1935). The Polish-German Antagonism in the Factory Settlement "Kopalnia" in Upper Silesia. Publisher unknown.

Kolberg, O. (n.d.). The People. (86 Volumes). Publisher unknown.

Tarkowska, E, Warzywoda-Kruszyńska, W and Wódz, K. (2003). Biedni o sobie i swoim życiu. Katowice: Śląsk.

Znaniecki, F and Thomas, W. (ed). Zarestsky, E. (1996). The Polish peasant in Europe and America. Illinois: University of Illinois Press

\section{Appendix I}

\section{National policies on data archiving and sharing}

1) Personal Data Protection Act from 1997 [Ustawa z dnia 29 sierpnia o ochronie danych osobowych ]. Full text in Polish available on the website of the Polish Parliament:

http://isip.sejm.gov.pl/servlet/Search?todo=open\&id= WDU19971330883

The most important legal act concerning protection of personal data in Poland is the Act of 29 August 1997 on the Protection of Personal Data. The act establishes the Inspector General and determines framework of the personal data processing. The Inspector General is competent in the issues concerning personal data protection and may inspect any subject who processes personal data. Entities which belong to the EEA (European Economic Area) are obliged to comply with the Act on the Protection of Personal Data only if they operate in the territory of Poland. This means that almost every company registered in Polish National Court Register have to comply with the Act. The main requirements for the data controller are:
- To process personal data on the basis of legal prerequisites
- To inform data subjects about their rights and the data controller status
- To register the data files in the Inspector General Office
- To secure the personal data from uncontrolled access
- To remove the personal data in case of a request from the data subject

Personal data usually cannot be transferred outside of EEA (European Economic Area) without prior approval of the data subject. However, it can be transferred without restrictions in the European Union and few other countries (e.g. Norway, Island, Lichtenstein).

Not applying the provisions of the Polish Act on Personal Data Protection can lead to criminal responsibility, in some cases even to three years of imprisonment. More often it leads to administrative proceeding.

Source: Law Firm Czuchaj and Partners www.czuchaj.pl 
2) The Civil Code (within the scope of research among children). Full and unified text in Polish available in on the website of the Polish Parliament:

http://isip.sejm.gov.pl/servlet/Search?todo=open\&id= WDU19640160093

3) ICC/ESOMAR International Code on Market and Social Research http://www.esomar.org/uploads/pdf/professional-standards/ ICCESOMAR_Code_English_.pdf

4) Qualitative Research Consultants Association (Code of Ethics and Guide to Professional Qualitative Research Practices)

http://www.qrca.org/displaycommon.cfm?an=1\&subarticlenbr=21

5) Control Program of the Quality of Work of Pollsters (Polish Association of Public Opinion and Marketing Research Firms) http://www.ofbor.pl/index.php?i=pkjpa\&id=1\&pg=1

\section{Appendix II}

\section{Other selected oral history initiatives that protect collected sources/ data}

Museum for the History of Polish Jews

(dozens of interviews with Poles who rescued Jews during WWII - project "Righteous Among the Nations")

Contact details: ul. Warecka 4/6, 00-040 Warszawa, web: www.jewishmuseum.org.pl

Tel: +48 2283300 21, email: Łucja Koch - Ikoch@jewishmuseum.org.pl

Center for Citizenship Education

(45 interviews with Poles who rescued Jews during WWII)

Contact details: ul. Noakowskiego 10, 00-666 Warszawa, web: www.ceo org.pl

Tel: +48 22 6220089, Marianna Hajdukiewicz (coordinator) - marianna@ ceo.org.pl

Christian Association of Auschwitz Families - project Memento (45 interviews with Auschwitz survivors, 200 hours, 1000 pages of transcriptions).

Contact details: ul. Partyzantów 1, 32-600 Oświęcim, web: www.auschwitzmemento.pl

Tel: +48 508-099-030, +48 503078 357, biuro@auschwitzmemento.pl

Lower Silesian Forum of Cultural Background "Milenium"

(130 interviews with people relocated to Lower Silesia after 1945)

Contact details: ul. Kowalska 58/28, 51-424 Wrocław, tel: +48 888315 334 ,

Juliusz Woźny - juliuszw@wp.pl

Museum of Warsaw Praga District

(several interviews with the oldest inhabitants of the district)

Contact details: ul. Targowa 45, 03-728 Warszawa, tel:+48 81810 77,

+48695645 501, muzeum.pragi@mhw.pl

European Solidarity Center

("Solidarity movement in my memory" - 20 interviews)

Contact details: Wały Jagiellońskie 1, 80-853 Gdańsk, tel: +48 58

3237056,

Monika Bogdanowicz - m.bogdanowicz@gdansk.gda.pl

Pedagogical Academy in Cracow, Institute of History
(150 interviews with people expelled from Polish Eastern Borders (Kresy) after 1945)

Contact details: ul. Podchorążych 2, 30-084 Kraków, tel: +48 604135 930,

Hubert Chudzio, PhD - hubert@ap.krakow.pl

Center "Remembrance and Future" in Wrocław

(interviews with Poles relocated to Polish Western Borderlands after 1945)

Contact details: al. gen. J. Hallera 8, 53 - 318 Wrocław; tel: +48 7133490 44,+48 663901 767, biuro@pamieciprzyszlosc.pl

Fundacja Kobieca eFKa

(Feminist organization conducting interviews with women in different gender-focused projects)

Contact details: ul. Krakowska 19, 31-062 Kraków, tel:+ 481243019 70, efka@efka.org.pl

And - last but not least - there are memorial sites, especially of former concentration camps, which collect, archive and make accessible oral history interviews with survivors. Most of these interviews are thematic ones - they focus on the camp experience. Most of these, however, treat texts of transcripts as the primary source and neglect the recordings.

Auschwitz Memorial

(3000 written accounts of former inmates, plus over a 100 audio and video interviews)

Contact details: ul. Więźniów Oświęcimia 20, 32 - 603 Oświęcim, tel: +48338431934

\section{Majdanek Memorial}

(interviews with former prisoners)

Contact details: Droga Męczenników Majdanka 67, 20-325 Lublin, tel:+48 8174426 47, sekretariat@majdanek.pl

Stutthof

(550 accounts of former prisoners - text, audio and video)

Contact details: ul. Muzealna 6, 82-110 Sztutowo, tel: +48552478353, stutthof@stutthof.pl

\section{Gross-Rosen Museum}

(206 video and 97 audio interviews with former prisoners) Contact details: ul. Szarych Szeregów 9, 58-304 Wałbrzych, muzeum@ gross-rosen.pl

Treblinka Museum (47 interviews)

Contact details: 08-330 Kosów Lacki, tel: +48-25-781-16-58, biuro@ muzeum-treblinka.pl

Bełżec Museum (80 interviews - all with transcriptions)

Contact details: Ofiar Obozu 4, 22-670 Bełżec, tel:+48 846652510 , muzeum@belzec.org.pl

\section{Notes}

1. Contact details of country reporters:

- Piotr Binder

pbinder@ifispan.waw.pl , tel: +48 505289998

Institute of Philosophy and Sociology, Polish Academy of Sciences

Nowy Swiat 72, 00-330 Warsaw, Poland 
- Piotr Filipkowski

p.filipkowski@karta.org.pl, tel: +48 694699470

Institute of Philosophy and Sociology, Polish Academy of Sciences

Nowy Swiat 72, 00-330 Warsaw, Poland

and

KARTA Center, Narbutta Str. 29, 02-536 Warsaw, Poland

2. Contact details:

Qualitative Data Archive [Archiwum Danych Jakościowych]

http://www.fispan.waw.pl/

archiwum_danych_jakosciowych/o_archiwum//

Nowy Świat 72, 00-330 Warsaw, tel: +48 226572852

Professor Hanna Palska - hpalska@poczta.onet.pl

Artur Kościański, PhD - akoscian@ifispan.waw.pl

3. Contact details:

KARTA, ul. Narbutta 29; 02-536 Warszawa, tel. +48 2284807 12, web: www.karta.org.pl; email: p.filipkowski@karta.org.pl

History Meeting House, ul. Karowa 20, 00-324 Warszawa, tel: +48 22

82625 78,www.dsh.waw.pl ; www.audiohistoria.pl ; email: ahm@dsh. waw.pl

4. Contact details: ul. Grzybowska 79, 00-844 Warszawa; tel: +48 22539 79 38; www.1944.pl; email:kontakt@1944.pl

5. Contact details: ul. Grodzka 21; 20-112 Lublin; tel. +48 8153258 67; www.tnn.pl; email: teatrnn@tnn.lublin.pl

6. Contact details:

Michał Łuczewski PhD, Warsaw University, Institute of Sociology, 18 Karowa St., 00-927 Warsaw, luczewskim@is.uw.edu.pl

\section{Contact details:}

Qualitative Data Archive [Archiwum Danych Jakościowych]

http://www.fispan.waw.pl/

archiwum_danych_jakosciowych/o_archiwum//

Nowy Świat 72, 00-330 Warsaw, tel: +48 6572852

Professor Hanna Palska - hpalska@poczta.onet.pl

Artur Kościański, PhD - akoscian@ifispan.waw.pl

8. Contact details:

Professor Elżbieta Tarkowska, Institute of Philosophy and Sociology, Polish Academy of Sciences, Department of Theory of Culture, Research Group of Poverty Studies

Nowy Świat 72,00-330 Warsaw, etarkows@ifispan.waw.pl

9. Contact details:

Monika Kwiecińska-Zdrenka, PhD, University of Nikolas Copernicus, Institute of Sociology,

Fosa Staromiejska 1a, 87-100 Toruń, monika.kwiecinska@umk.pl

10. Contact details:

Professor Kazimierz M. Słomczyński, Institute of Philosophy and Sociology, Polish Academy of Sciences, Research Group of Comparative Analysis of Social Inequalities, Nowy Świat 72, 00-330 Warsaw, kms0543@aol.com 